\title{
Somaclonal Variation in Tissue Culture: A Case Study with Olive
}

\author{
A.R. Leva, R. Petruccelli and L.M.R. Rinaldi \\ Additional information is available at the end of the chapter
}

http://dx.doi.org/10.5772/50367

\section{Introduction}

Micropropagation of woody plants and fruit crops constitutes a major success in the commercial application of in vitro cultures. An important aspect to be considered when deriving perennial plants from micropropagation is the maintenance of genetic integrity with regard to the mother plant. In this regard, somaclonal variation has been reported at different levels (morphological, cytological, cytochemical, biochemical, and molecular) in micropropagated plants [1]. The economic consequence of somaclonal variation among regenerated plants is enormous in fruit crops and woody plants, because they have long life cycles. In consequence, the behaviour of micropropagated plants should be assessed after their long juvenile stage in field conditions. The occurrence of somaclonal variation is a matter of great concern for any micropropagation system. In order to evaluate its presence several strategies were used to detect somaclonal variants, based on one or more determinants from among morphological traits, cytogenetic analysis (numerical and structural variation in the chromosomes), and molecular and biochemical markers [2]. In addition, studies on somaclonal variation are important for its control and possible suppression with the aim of producing genetically identical plants, and for its use as a tool to produce genetic variability, which will enable breeders the genetic improvement. Somaclonal variation has been studied extensively in herbaceous plants, whereas few studies have focused on temperate perennial fruit crops.

This chapter provides a survey of the technical approaches for identifying somaclonal variation in perennial fruit crops and is intended to provide a synthesis of the literature on the topic. In addition, recent advances in the characterization and detection of somaclonal variation in olive plants produced in vitro by nodal explants and somatic embryogenesis are reported in detail. 


\section{Somaclonal variation}

In nature, the genetic diversity and variability within a population are generated via recombination events. Factors such as natural selection, mutation, migration and population size influence genetic variability in different ways. In 1958 a novel, artificially produced, source of genetic variability was reported [3], the higher plant cells cultured in vitro showed a genetic instability that was also characteristic of regenerated cells. The first observation of somaclonal variation was reported [4]. Subsequently, the variability existing in plant tissue and cell cultures received much attention and neologisms were proposed by Larkin and Scowcroft [5] to refer to the results of in vitro cultures of plants. The term 'somaclone' was coined to refer to plants derived from any form of cell culture, and the term 'somaclonal variation' was coined to refer to the genetic variation among such plants. The growth of plant cells in vitro and their regeneration into whole plants is an asexual process that involves only mitotic division of the cells. In this context, the occurrence of uncontrolled and random spontaneous variation when culturing plant tissue is a major problem [6]. In vitro, the conditions of culture can be mutagenic and regenerated plants derived from organ cultures, calli, protoplasts and somatic embryos sometimes can show phenotypic and genotypic variation [7]. Some, or all, of the somaclones may be physically different from the stock donor plants [8]. Usually, variability occurs spontaneously and can be a result of temporary changes or permanent genetic changes in cells or tissue during in vitro culture. Temporary changes result from epigenetic or physiological effects and are nonheritable and reversible [9]. In contrast, permanent changes are heritable and often represent expression of pre-existing variation in the source plant or are a result of de novo variation [5]. The literature to date indicates that somaclonal variation can range in scope from specific trait to the whole plant genome. Somaclonal variation provides a valuable source of genetic variation for the improvement of crops through the selection of novel variants, which may show resistance to disease, improved quality, or higher yield [10, 11, 12, 13].

\section{Origin and causes}

Although somaclonal variation has been studied extensively, the mechanisms by which it occurs remain largely either unknown or at the level of theoretical speculation in perennial fruit crops [14,15]. A variety of factors may contribute to the phenomenon. The system by which the regeneration is induced, type of tissue, explant source, media components and the duration of the culture cycle are some of the factors that are involved in inducing variation during in vitro culture [16].

\subsection{Regeneration systems}

Regeneration systems can be ranked in order from high to low in terms of genetic stability, as follows: micropropagation by preformed structures, such as shoot tips or nodal explants; adventitiously derived shoots; somatic embryogenesis; and organogenesis from callus, cell and protoplast cultures $[17,18]$. Cellular organization is a critical factor for plant growth, 
whereas in vitro the loss of cellular control, which gives rise to disorganised growth, is a characteristic of somaclonal variation $[6,19]$.

Although the direct formation of plant structures from meristem cultures, without any intermediate callus phase, minimises the possibility of instability, the stabilising influence of the meristem is sometimes lost in vitro cultures [6].

Somatic embryogenesis and enhanced axillary branching are the methods used most extensively in commercial micropropagation systems [20]. Somatic embryogenesis has the potential to produce the greatest number of plantlets in a short time, and makes possible the use of bioreactors for the large-scale production of somatic embryos [21] and their delivery through encapsulation into artificial seeds [22, 23, 24, 25]. Enhanced axillary branching involves the abolition of apical dominance to achieve the de-repression and multiplication of shoots, and has become a very important method on account of the simplicity of the approach and rapid propagation rate [26, 27]. These methods are considered to produce genetically uniform and true-to-type plants, because the organised meristems generally are believed to be immune to genetic changes $[28,29]$. Several reports of experimental studies support this view $[30,31,32,33,34,35]$. However, there is an increasing body of evidence that indicates that in embryogenic cultures, selection in favour of 'normal cells' does not always take place during development and that growth of mutant cells can occur as well, which can induce variability in the cultures [36].

\subsection{Explant source}

Genetic fidelity largely depends on explant source [37]. The explant tissue can affect the frequency and nature of somaclonal variation [38,39]. The use of meristematic tissues, such as the pericycle, procambium and cambium, as starting materials for tissue culture reduces the possibility of variation [40]. In contrast, highly differentiated tissues, such as roots, leaves, and stems, generally produce more variants, probably due to the callus-phase, than explants that have pre-existing meristems [41]. Furthermore, preparation of many explants from only one donor plant increases the possibility of variation in cultures [42]. This illustrates the importance of the donor plant with respect to its inherent genetic composition and genome uniformity in any of its components. Somaclonal variation can arise from somatic mutations already present in the tissues of the donor plant [6]. To test for pre-existing somaclonal variation, the somatic embryos obtained in the first round of regeneration may be subjected to another round of in vitro regeneration. Tissues that show pre-existing variation should yield more variability in the first somaclonal generation than in the second generation, and thereafter the variation in the second round can be eliminated or stabilised [15].

\subsection{Medium components}

The hormonal components of the culture medium are powerful agents of variation. The effect of the type and concentration of plant growth regulators on the incidence of somaclonal variation in different plant species remains a topic of debate. Unbalanced concentrations of auxins and cytokinins may induce polyploidy, whereas under a low 
concentration or total absence of growth regulators the cells show normal ploidy [43]. In addition, rapid disorganised growth can induce somaclonal variation [6]. Sub- and supraoptimal levels of growth regulators, especially synthetic compounds have been linked with somaclonal variation [44, 45]. Auxins added to cultures of unorganised calli or cell suspensions increase genetic variation by increasing the DNA methylation rate [46]. Similarly, in callus cultures of strawberries, the presence of the synthetic auxin 2,4Dichlorophenoxyacetic acid (2,4-D) is often associated with genetic abnormalities, such as polyploidy and stimulation of DNA synthesis, which may result in endoreduplication [47, $48,49,50]$. It would seem that growth regulators preferentially increase the rate of division of genetically abnormal cells [51]. High levels of cytokinins do not directly affect the rate of somaclonal variation in the banana cultivars 'Nanjanagudu Rasabale' and 'Cavendish'; in this contest it would seem that the genotype has the greatest effect on somaclonal variation $[52,53]$. Conversely, high levels of benzyladenine (BA) cause the number of chromosomes in the banana cultivar 'Williams' to increase [54]. In addition, diphenylurea derivatives are implicated in the incidence of somaclonal variation in bananas [55].

\subsection{Duration and number of culture cycles}

The frequency of somaclonal variation increases as the number of subcultures and their duration increases, especially in cell suspensions and callus cultures [56, 57, 58]. Moreover, the rapid multiplication of a tissue or long-term cultures may affect genetic stability and thus lead to somaclonal variation [59, 56, 60]. A statistical model has been proposed for predicting the theoretical mutation rate, primarily on the basis of the number of multiplication cycles [61]. However, the model has limited application, due to the complexity of biological systems.

\subsection{Effect of genotype}

Conditions of culture in vitro can be extremely stressful for plant cells and may initiate highly mutagenic processes $[62,63]$. However, different genomes respond differently to the stress-induced variation, which indicates that somaclonal variation also has genotypic components. In callus cultures of strawberry, the genotype and type of explant strongly influenced the occurrence of somaclonal variation [64]. The differences in genetic stability are related to differences in genetic make-up, because some components of the plant genome may become unstable during the culture process, for example the repetitive DNA sequences, which can differ in quality and quantity between plant species [65]. In banana tissue culture the most important factor that influenced dwarf off-type production was found to be the inherent instability of the cultivars; for example, the cultivar 'New Guinea Cavendish' showed a higher level of instability in vitro than 'Williams'. The dwarf off-types remained stable during in vitro culture, and the conditions under which tissue was cultured that induced dwarfism did not induce reversion of the dwarf off-type trait [66]. In Musa species, the type and rate of variation was specific and depended on genotype $[67,68]$ and genome composition [40]. An interaction between genotype and the tissue culture environment is also reported [69]. 


\section{Genetic changes that contribute to somaclonal variation}

During plant growth and development in vivo, gross changes in the genome can occur during somatic differentiation, including endopolyploidy, polyteny and amplification or diminution of DNA sequences [70]. The processes of dedifferentiation and redifferentiation of cells may involve both qualitative and quantitative changes in the genome, and different DNA sequences may be amplified or deleted during the cell reprogramming. In addition, this process is related closely to the tissue source and the regeneration system [65]. Gross and cryptic chromosomal changes, or extensive changes in chromosome number, occur early during induction in an in vitro culture [5]. Variation in chromosome numbers and structures, and chromosome irregularities (such as breaks, acentric and centric fragments, ring chromosomes, deletions and inversions) are observed during in vitro differentiation and among regenerated somaclones [71, 72, 5]. Such rearrangements in chromosomes may result in the loss of genes or their function, the activation of genes previously silent, and the expression of recessive genes, when they become haploid. The irregularities in the chromosomes may be lost during plant regeneration and result in the production of 'normal' plants, or appear in the regenerated somaclones.

Cryptic changes, such as point mutations, are also expected to occur and may affect the chloroplast or mitochondrial genomes. In addition, transpositional events, such as the activation of transposable elements, putative silencing of genes and a high frequency of methylation pattern variation among single-copy sequences, play a role in somaclonal variation $[73,74]$.

The tissue culture environment may result in the modification of DNA methylation patterns $[62,75]$. Global methylation levels and methylation of specific sites are documented in several crops, e.g. oil palm [76], grapevine [77, 78] and apple [79]. In addition, epigenetic changes, such as DNA methylation and histone modifications, may be associated with the physiological responses of the plant cells to the conditions in vitro [75]. Several epigenetic systems have been studied: variation for morphological traits, such as flower colour and shape, leaf colour and shape, and plant height; resistance to disease; and maturity date [80]. The rate of these changes varies not only in response to tissue culture conditions, but also among species and even among cultivars of the same species [81].

There are several extensive reports of morphological and genetic variation of several plant species, primarily herbaceous species, but few studies have been conducted on perennial fruit crops, which indicates that knowledge of somaclonal variation in these plants is lacking [1]. Currently, many markers are available to verify the fidelity of perennial fruit crops at the morphological, physiological and molecular levels.

In light of the many factors that can lead to somaclonal variation, the characterisation of micropropagated plants is essential to help to modify the protocol/s with which genetically true-to-type plants are obtained, so that the procedures can be used with predictable results. 


\section{Morphological, cytological and biochemical markers}

Morphological markers usually are used to identify species, genera and families in germplasm collections. Somaclonal variants can be detected easily by morphological characteristics, such as plant height, leaf morphology and abnormal pigmentation [68]. For example, a sweet cherry (Prunus avium) somaclonal variant was characterised by morphological parameters, namely evaluation of plant vigour, leaf morphology, stomatal density, photosynthesis activity, the formation of floral buds, and the size, shape and colour of the fruit [82].

Chromosomal alteration and ploidy changes are highlighted by cytogenetic analysis, including chromosome counting and/or flow cytometry. Cytometry has been used to identify the particular characteristics of somaclonal variation in Vitis vinifera $[83,84,85]$ and Citrus lemon [7]. Proteins and isozymes have been used widely as markers for identifying cultivars and characterising somaclonal variation in many fruit species [33]. Isozyme analysis has been used to assess genetic fidelity in Citrus plants regenerated through organogenesis, and somatic embryogenesis [86].

\section{Molecular markers}

In some instances, discrepancies between molecular markers and phenotypic data are observed [87]. These discrepancies relate to the complexity of the plant genome, and the markers that are normally used often cannot give a complete view [88]. To resolve this difficulty, assay at the molecular level should be examined in relation to morphological changes. Currently, different molecular analytic techniques have used to point out somaclonal variation in tissue culture and in regenerants of several plants. Randomly amplified polymorphic DNA (RAPD), amplified fragment length polymorphism (AFLP), simple sequence repeat (SSR) and inter-simple sequence repeat (ISSR) markers have been used to study the genetic fidelity or genetic variability in micropropagated fruit crops.

RAPD markers are suitable for detecting somaclonal variation in Prunus persica and the variation observed is genotype-dependent [89]. In contrast, RAPD fingerprinting confirmed genetic fidelity in microcuttings of Cedrus libani [90], micropropagated plants of Cedrus atlantica and C. libani [91], plants regenerated from leaf explants of Citrus sinensis cv. Bingtangcheng and cv. Valencia [92], and in Citrus limon plants [7]. Moreover, RAPD analysis showed clonal stability in micropropagated plants of Pyrus [93], and in plants of hazelnut (Corylus) regenerated from long-term in vitro cultures [94]. Polymorphic RAPD marker have been observed in apple and pear cultivars regenerated from adventitious shoots [95, 96], whereas no polymorphism was observed in apple and pear cultivars regenerated from vegetative shoot apices [96]. No polymorphism in RAPD markers was observed between plants propagated in vitro and donor plants of clones of the hybrid Castanea sativa $\times$ C. crenata [97].

AFLP markers have been used to assess both genetic variation among axillary shoots and shoots regenerated from leaf- and petiole-derived calli of kiwifruit (Actinidia deliciosa). [98]. 
A close relationship between the type of explants, regeneration system, and the presence of somaclonal variation was detected in shoots regenerated from leaf callus [99].

Plants of Vitis vinifera cvs. Mission and Valerien regenerated from callus cultures showed polymorphism using methylation-sensitive restriction enzymes [100].Variation in DNA methylation has been highlighted in apple plants micropropagated from in vitro axillary shoot cultures [101].

SSR markers were applied to different $V$. vinifera cultivars regenerated from shoot cultures and from anther and ovary embryogenic callus lines. Homogeneous amplification profiles were revealed in the in vitro samples and donor plants [102]. In addition, SSR markers revealed genetic stability in V. vinifera cv. Crimson Seedless shoot cultures [103] and in micropropagated plants of the apple rootstock Merton 793 [104].

In general, the use of one type molecular marker to assess the stability of in vitro propagated plants may be insufficient. Recently, several authors used multiple molecular marker types to study somaclonal variation in regenerants of several plant species. In Actinidia deliciosa cultures, a relatively low level of polymorphism was detected with RAPD markers, whereas with SSR markers the level of polymorphism detected was higher [105]. Genetic stability was analyzed in plantlets of almond (Prunus dulcis) regenerated by axillary branching with RAPD markers and confirmed by ISSR analysis [106]. The genetic fidelity of plantlets obtained by indirect somatic embryogenesis from anthers and ovaries of $V$. vinifera $\mathrm{cv}$. Grignolino and cv. Dolcetto was detected by SSR and AFLP analysis [107].

\section{Olives}

Olives belong to the genus Olea (family Oleaceae). The genus comprises 35 species, of which the most important is O. europaea, which comprises two subspecies subsp. sylvestris (wild olive) and subsp. europaea (cultivated olive). Olive cultivars are subdivided into two types: i) olive-oil cultivars, which are used for the production of olive oil, in which the ripe fruit contains at least $20 \%$ oil; and ii) table cultivars, which produce fruits with a lower oil content and are destined for canning. Olive cultivation is concentrated in southern Europe (Spain, Italy, France, Portugal and Greece) and the Mediterranean region (Turkey, Syria, Libya, Morocco and Tunisia). The olive is the longest-cultivated crop in the Mediterranean basin and the most economically important fruit tree in this part of the world. Over the last few decades, cultivation has expanded to other countries, such as South Africa, Argentina, Chile, the USA (in California), Australia and China. Currently, 9.4 million ha of olive orchards worldwide produce about 16 million tons of olive fruits that are processed into 2.5 million tons of oil and 1.5 million tons of table olives. For centuries, olive plants have been propagated vegetatively by suckers, grafting and cuttings. In vitro culture offers a novel alternative method of propagation to these traditional approaches.

We report the studies conducted on olive plants produced in vitro by nodal explants and somatic embryogenesis to verify their fidelity to donor plant. 


\subsection{Regeneration systems for olive}

The ability of a single cell to divide and give rise to a whole plant (cellular totipotency), is the theoretical and experimental basis of modern plant biotechnology. Perennial and woody plants generally are considered to be recalcitrant in culture and are difficult to regenerate [108]. In commercial regeneration systems, the two methods that are used most commonly for olive plants are micropropagation and somatic embryogenesis.

\subsubsection{Micropropagation}

Schaeffer [109] defined micropropagation as the in vitro clonal propagation of plants from shoot tips or nodal explants; in the case of olive, nodal explants are used. Indirect systems, such as the differentiation of adventitious shoots after a phase of disorganised callus formation, are used less frequently for perennial plants because of the possible selection of several cell-lines in callus. The multicellular origin of adventitious buds is considered to generate a high risk that the regenerated plants will lose fidelity to the parent plant. In a commercial setting, this threat is often serious enough to eliminate any further consideration of micropropagation as a cloning method.

In vitro vegetative propagation by nodal explants allows rapid production of a large number of plants. The procedure consists of the following stages: culture establishment, shoot proliferation, rooting and acclimatization extra vitro (Figure 1). Therefore, the degree of success depends on the genotype, selection of explants, media and culture conditions, and levels of growth regulator. The micropropagation of olives was first achieved a quarter of a century ago [110, 111, 112]. However, progress in improving the technique has been relatively slow, due to the inherently slow growth of olive explants. The rate of proliferation of olive explants is limited by the low frequency of bud sprouting and poor growth rates of secondary shoots [113, 114, 115]. In recent years, several studies have investigated and improved the technique to define an in vitro propagation sufficiently effective for large-scale commercial application [116].
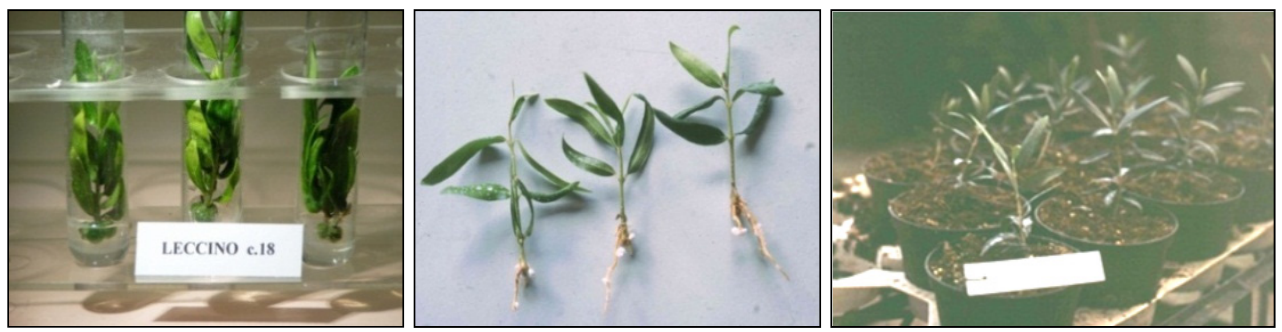

Figure 1. Stages of micropropagation by nodal explants of olive plants following from left to right: Stage $1=$ shoots proliferation; Stage $2=$ rooting of shoots; Stage 3 = acclimatization of shoots ex vitro 


\subsubsection{Somatic embryogenesis}

This regeneration system has been well documented in several species, using a wide range of plant tissues as explant sources. Immature embryos are suitable for induction of embryogenesis. This capability is, in most instances, not merely an intrinsic property of a species and instead is under genetic control, such that individual genotypes within a species can differ in their ability to undergo somatic embryogenesis. The first report of somatic embryogenesis in olive used a portion of cotyledons from immature embryos [117, 118] (Figure 2). Subsequent studies have focused on the induction of somatic embryogenesis in different olive cultivars $[119,120,121]$. Improved protocols have enabled the induction of somatic embryogenesis from mature tissues (petioles) obtained from shoots grown in vitro [119] portions of the radicle and cotyledons [122], ovaries, stamens, leaves and petioles $[123,124]$, and cell suspension cultures derived from mature olive tissue [125].
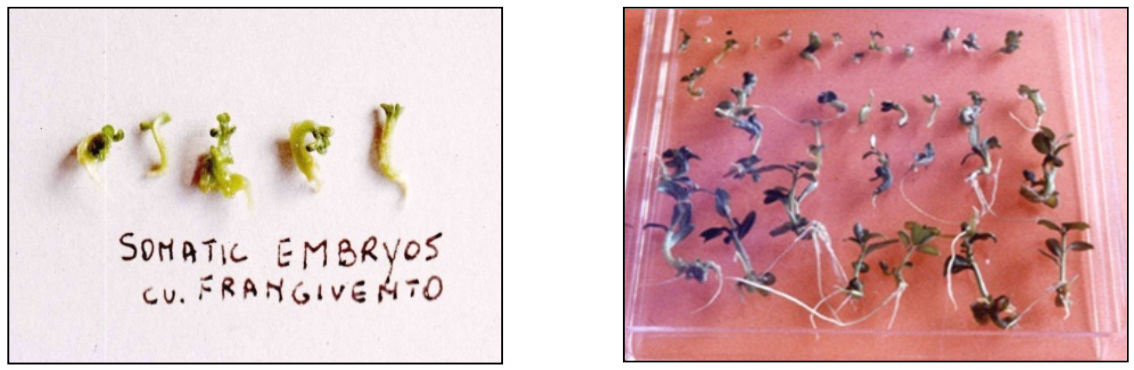

Figure 2. Somatic embryos of cv Frangivento at different development stages

\subsubsection{Propagation by nodal explants and somatic embryogenesis compared}

Micropropagation has a significant advantage over somatic embryogenesis in that it is thought to reduce the potential for undesirable somaclonal variants among the regenerated plants, whereas in somatic embryogenesis the risk of genetic instability is high. Somatic embryogenesis has an advantage over micropropagation in that it generates a new plant with both root and shoot meristems from actively dividing somatic cells in the same step and within a short time period, whereas micropropagation requires additional steps and a longer time frame.

\subsection{Field performance of olive plants raised in vitro}

Despite the commercial importance of clonal fidelity of plants produced by tissue culture, the field performance and genetic integrity of olive plants regenerated from in vitro cultures is reported sporadically [126, 127, 128]. These factors are of paramount importance for olive cultivars. Olive trees have a long life span (hundreds of years), a long juvenile period, broad genetic diversity and consequent variability of the fruit, which may influence traits that pertain to the composition and quality of the oil, such as aroma and taste [129]; hence, any variation of the genotype may modify the olive oil characteristics. From this point of view it 
is critical that the morphological and molecular performance of mature plants, derived from axillary buds and somatic embryogenesis, should be evaluated.

\subsubsection{Morphological characterisation of plants derived from nodal explants}

Morphological and biological characteristics have been used widely for descriptive purposes and are commonly used to distinguish olive cultivars [130]. A morphological approach is the main initial step when describing and classifying olive germplasm (131]. So, a morphological analysis was used initially to evaluate the plants produced by micropropagation (termed 'micropropagated plants'; MPs) using the protocol reported in $[113,132]$ and in [116].

The donor plant (DP) for the initial explants for micropropagation was a 20-year-old tree of Olea europaea cv. Maurino. The same donor plant, multiplied by cuttings, was used as the control plant in the field evaluation. In 1998, 70 16-month-old MPs cultured in pots and 20 control plants $(\mathrm{Cp})$ were transferred to an experimental field situated in San Pancrazio, Firenze, Italy $\left(43^{\circ} 39^{\prime} 36.00^{\prime \prime} \mathrm{N}, 1^{\circ} 11^{\prime} 25.80^{\prime \prime}\right.$ E). Twenty-four morphological parameters for vegetative and reproductive traits were considered (Table 1).

During field growth, no significant differences in most of the vegetative parameters were noted between the MP and Cp plants. The data revealed no differences in growth habit, vegetative growth, and canopy and trunk area. Only the leaves and drupes of MPs were slightly wider than the $\mathrm{Cp}$ plants but still retained the characteristic leaf and drupe shapes of the cultivar. The productivity of fruiting shoots was similar, despite the slightly different number of flowers per inflorescence; in olive fruit set only occurs in $2-5 \%$ of the flowers, so the slight difference did not have any effect on fruiting [133]. Pit traits were identical between the MP and Cp plants (Figure 3). Olive oil was extracted from both plant groups and subjected to sensory tests and chemical composition analysis. The oils had a strong fragrance and there was no variability in composition between the oil produced by the MP and $\mathrm{Cp}$ plants (Figure 4). Thus, the MP plants showed morphological and productive uniformity with the $\mathrm{Cp}$ plants in terms of vegetative, reproductive and oil traits. Any genetic variation present among the MPs was unrelated to development, vegetative growth and production quality. These results are related to the protocol used for in vitro culture. It is important to stress the absence of relevant somaclonal variation because, as reported by Rani and Raina [1], a procedure for micropropagation should be released for commercial application only when analyses on mature plants have established that the procedure does not induce undesirable somaclonal variation.

\begin{tabular}{|l|l|}
\hline \multicolumn{1}{|c|}{ Vegetative characters } & \multicolumn{1}{|c|}{ Inflorescence and fruit characters } \\
\hline $\begin{array}{l}\text { HP Plant height: measured in meter from } \\
\text { the soil level to the highest point }\end{array}$ & *IL Inflorescence length in $\mathrm{mm}$ \\
\hline $\begin{array}{l}\text { CP Canopy projection to the soil: measured } \\
\text { at the two widest diameters in } \mathrm{m} 2\end{array}$ & NF Number of flowers per inflorescence \\
\hline
\end{tabular}




\begin{tabular}{|c|c|}
\hline Vegetative characters & Inflorescence and fruit characters \\
\hline VP Canopy volume in $\mathrm{m}^{3}$ & NO Number of olive fruits per fruiting shoot \\
\hline TA Trunk area in $\mathrm{cm}^{2}$ & FL Fruit length in $\mathrm{mm}$ \\
\hline VSG Vegetative shoot growth in $\mathrm{cm}$ & FW Fruit width in mm \\
\hline VSN Node number of vegetative shoots & FL/W Fruit length/width \\
\hline $\begin{array}{l}\text { VSI Internode length of vegetative shoots in } \\
\mathrm{cm}\end{array}$ & FFW Fruit fresh weight in $g$ \\
\hline $\begin{array}{l}\text { *FS Number of feather shoots (lateral shoots } \\
\text { developing from axillary buds formed in } \\
\text { same year) on the vegetative shoots }\end{array}$ & FDW Fruit dry weight in $g$ \\
\hline *FG Feather shoot growth in $\mathrm{cm}$ & PL Pit length in mm \\
\hline${ }^{*}$ FN Feather shoot node number & PW Pit width in mm \\
\hline *FI Internode length of feather shoots in $\mathrm{cm}$ & PL/W Pit length/width \\
\hline LBL Leaf blade length in $\mathrm{mm}$ & PFW Pit weight in $\mathrm{g}$ \\
\hline LBW Leaf blade width in $\mathrm{mm}$ & FFW/PW Fruit weight/Pit weight \\
\hline BL/W Blade length/width & FY Production weight in $\mathrm{Kg}$ \\
\hline \multicolumn{2}{|l|}{ LA Leaf area in $\mathrm{mm}^{2}$} \\
\hline \multicolumn{2}{|l|}{${ }^{*}$ LFW Leaf Fresh weight in mg } \\
\hline \multicolumn{2}{|l|}{${ }^{*}$ LDW Leaf Dry weight in mg } \\
\hline${ }^{*}$ DW Dry weight mg per $100 \mathrm{~mm}^{2}$ & \\
\hline
\end{tabular}

*no used for microplants

Table 1. Quantitative descriptors of olive plants propagated through nodal explants, and somatic embryogenesis observed in field cultivation

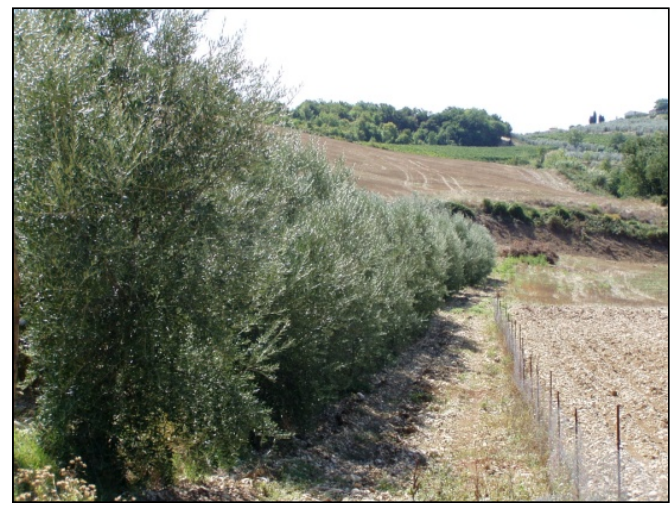

Figure 3. Micropropagated olive orchard 


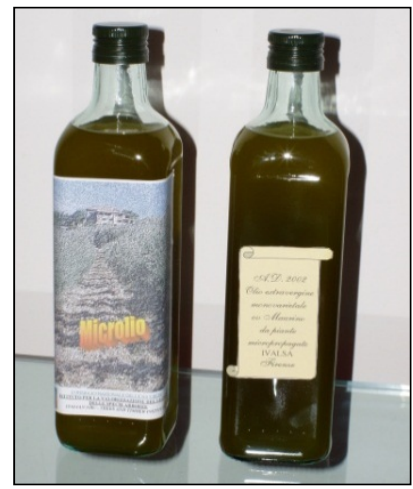

Figure 4. Olive oil extracted by micropropagated plants

\subsubsection{Molecular characterisation and assessment of genetic fidelity of plants derived from} micropropagation

At the end of the second year of field cultivation, an initial molecular analysis was conducted on five MP, Cp plants and the donor plant. Twenty-one 10-base primers were used for PCR-RAPD analysis. The primers generated a total of 182 amplification fragments. All of the primers produced monomorphic amplification patterns in the MPs, and no differences were found in the amplification pattern among MPs, Cps and donor plant.

In 2006, 12 randomly chosen 9-year-old mature MPs were evaluated by means of RAPD and ISSR analysis. Total genomic DNA was extracted from fresh leaves of the MPs and donor plant using the DNeasy Plant Mini Kit (Qiagen, Hilden, Germany). To detect any genetic changes, the RAPD and ISSR results were compared among all MPs, and between MP and Cp plants. The 40 RAPD primers generated 301 scorable band classes, whereas the 10 ISSR primers produced 46 reproducible fragments. The RAPD primer amplification products were monomorphic in MPs and donor plant, as well as the ISSR primers produced monomorphic bands within MPs, and between MP samples and donor plant [134] (Figure 5).

The molecular analyses, undertaken in two separate studies, at different plant ages, and using two types of molecular markers, supported the genetic stability and uniformity of Olea europaea cv. Maurino MPs. In addition, these results confirmed the reliability of the morphological analysis results $[127,128]$.

\subsubsection{Morphological characterisation of plants regenerated by somatic embryogenesis}

Plantlets were obtained from embryogenic tissue induced from immature cotyledons of the cultivar Frangivento using the methods reported in reference [118], (Figure 2). Fifty somatic seedlings were recovered from embryogenic long-term cultures (3 years), planted in small commercial pots $(1.5 \mathrm{l})$ and placed in a greenhouse in 1992. The survival frequency was $83 \%$ after 3 months. The somatic seedlings and MPs from Frangivento donor plant, which was used as a putative control $(\mathrm{Pc})$, were grown in large pots in a greenhouse up to 1997. During 
cultivation in pots, the somatic plants showed developmental behaviour related to growth rate and habit that differed from that of the MPs. In 1998, 43 somatic plants and 10 Pc plants were

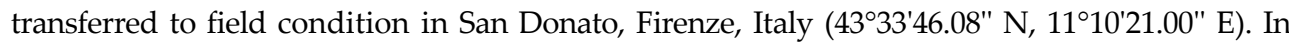
the field, the somatic plants retained the different developmental behaviour observed in pots. The plants were monitored for several years, during which time it was possible to detect morphological variation related to potential yield, inflorescences, fruits and their characteristics. In total, 32 morphological traits were analysed (Table 1). On the basis of the preliminary observations of plant growth in pots, in the field we recorded, in particular, data for two variant phenotype groups classified as bush olive somaclones (BOS; four representative trees) and columnar olive somaclones (COS; four representative trees) (Figure 6).

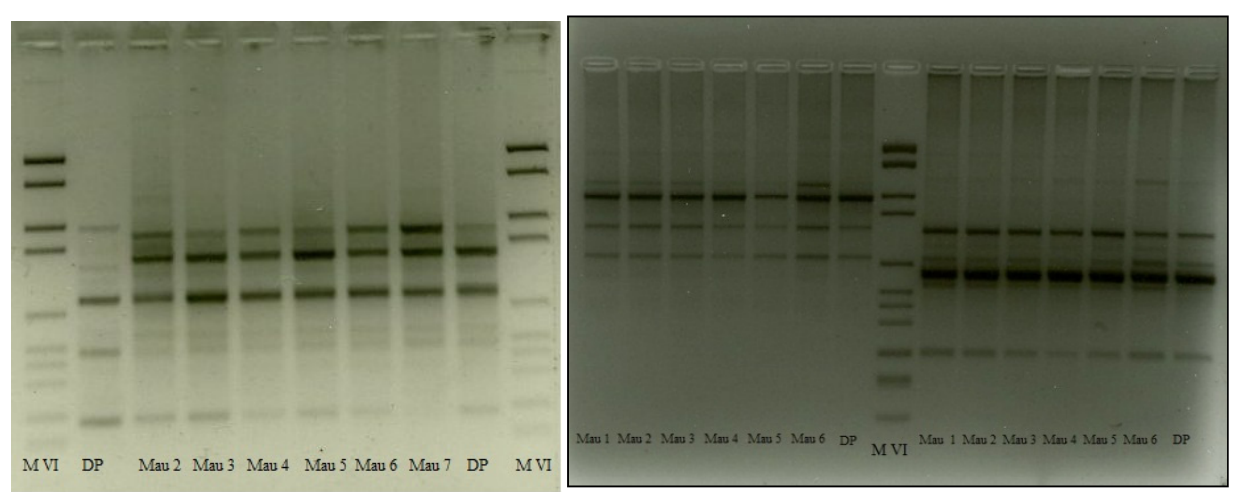

Figure 5. RAPD-PCR amplification patterns for micropropagated plants cv Maurino (Mau) and donor plant (DP) using primers left:M10 right SAT3 and 40148. MVI markers
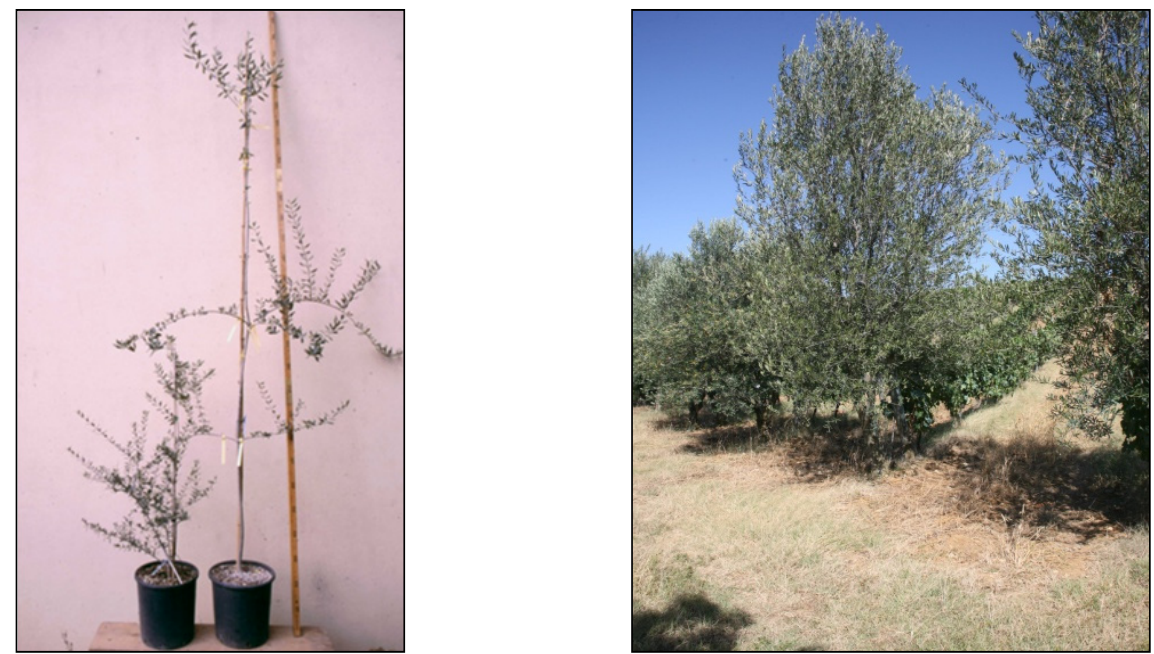

Figure 6. Somaclonal olive plants: BOS and COS phenotypes, left: somaclones during the growth in pots in greenhouse, right: mature somaclones grown in experimental field 
Four replicates for each phenotype were chosen in agreement with the number of replicate plants in an olive germplasm collection, according to the International Union for the Protection of New Varieties of Plants descriptor list. The relationships among the BOS and COS groups and Pc plants were investigated by analysis of variance for morphological traits and by a multivariate method (cluster analysis).

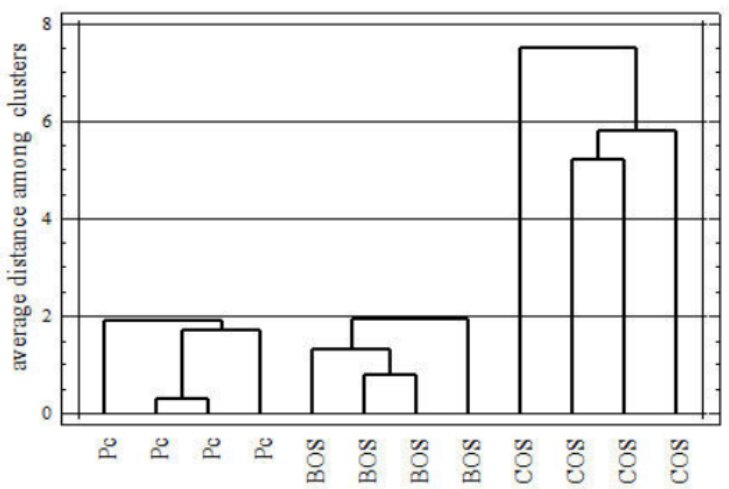

Figure 7. Dendrogram based on morphological traits of the BOS, COS groups and Putative control (Pc) according to a hierarchical clustering.

Wide phenotypic variation in shoot growth responses was observed between the BOS and COS groups. The differences were related to the growth rate, leaf, fruit and pit traits. The architecture of the COS plants, which is determined by plant height, canopy projection and canopy volume, differed from that of Pc plants. In the BOS plants, the reduction in plant height, increase in feather shoot number, and reduction in the dimensions of the leaves, inflorescences and fruits, jointly contributed to the more compact growth habit than that of the Pc plants. Cluster analysis was able to separate and characterise the BOS and COS groups from the Pc plants, as expected, on the basis of the different growth habits and dimensions of the leaf, fruit, pit and inflorescence (Figure 7) [128].
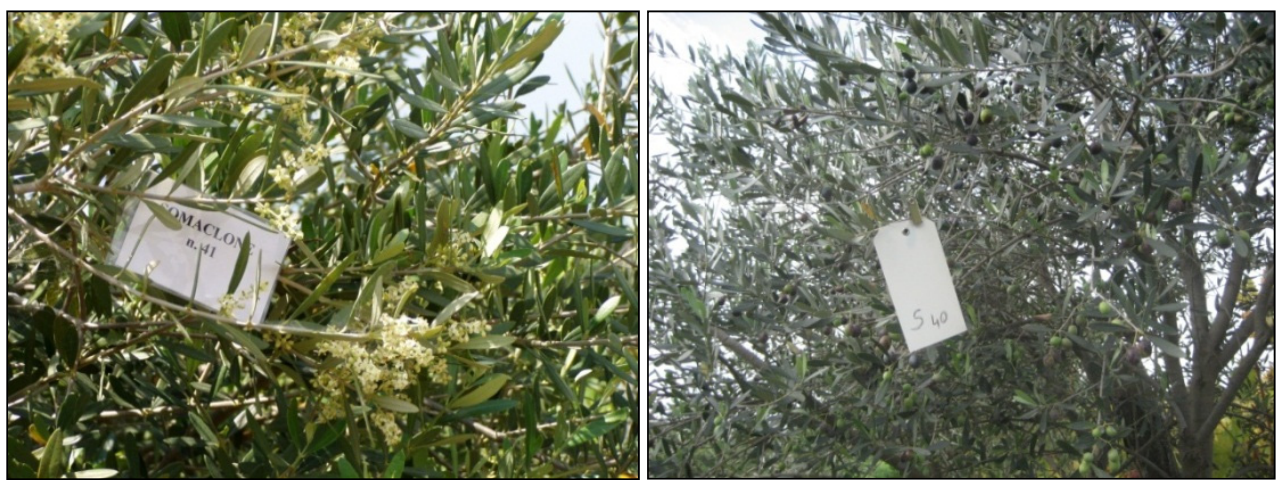

Figure 8. Somaclonal olive plants, left: flowering, right: fruiting 
The morphological variations detected among the somaclonal plants were positive and important variations for a possible future utilization of somaclones as rootstocks or new genotypes, and were not accompanied by deleterious changes in other agronomically or horticulturally important traits (Figure 8).

Our results on somaclonal variation among olive plants produced by somatic embryogenesis are in agreement with preliminary data recorded for field-grown juvenile olive plants derived from embryogenic callus of the cultivar Moraiolo [135].

\subsubsection{Molecular characterisation of somaclonal olive plants}

Bush olive somaclone (BOS), columnar olive somaclone (COS) and Frangivento donor plants grown in the field were analysed with RAPD molecular markers. Total genomic DNA was extracted from fresh leaves using the DNeasy Plant Mini Kit (Qiagen, Hilden, Germany). As a first step, 40 primers (decamers) were used [136], of which 20 primers showed reproducible and well-resolved bands. All subsequent analyses were conducted using these 20 primers.

The 20 RAPD primers generated 198 scorable band classes that ranged in size from 2200 to $210 \mathrm{bp}$; the number of primer bands varied from seven (CD11 and OPA01) to 13 (OPP10, AH30 and OPP12). Both somaclone types and Frangivento shared a large proportion (86\%) of RAPD markers, which suggested the occurrence of homology among the somaclones and Frangivento. These results were expected because all regenerants were derived from the same seed (two cotyledon portions). In addition, the results suggest that genetic changes occurred during the long-term maintenance of embryogenic cultures in vitro.

Some primers showed polymorphism between the somaclones and the donor plant, whereas others were polymorphic between the BOS and COS groups. Eight primers (OPP15, OPP10, AH29, AG1, OPP12, OPA07, OPP14 and OPP02), showed a close relationship with growth habit (Table 2). The type of polymorphism detected was either presence or absence of a fragment. The primer OPP15 amplified a single, intense band of approximately $537 \mathrm{pb}$ in COS plants, but this band was absent in BOS plants and Frangivento. In addition, the primer OPP10 amplified two specific bands: a single band of approximately $603 \mathrm{pb}$ present only in BOS plants, and a specific band of approximately 425 pb present in COS plants. OPP14 amplified a specific band present in all somaclones but absent in Frangivento donor plant. Eight polymorphic primers amplified seven specific bands (OPP10603, AH29 1190 , AG1550, OPP121350, OPA07407, OPA07340 and OPP02750) for BOS plants and three specific bands (OPP15537, OPP10425 and OPP02800) for COS plants.

\begin{tabular}{|c|c|c|c|c|}
\hline Primer & Fragments $(\mathbf{p b})$ & COS & BOS & DP \\
\hline OPP15 & 1000 & - & + & + \\
\hline & 537 & + & - & - \\
\hline & 375 & - & + & + \\
\hline
\end{tabular}




\begin{tabular}{|c|c|c|c|c|}
\hline Primer & Fragments (pb) & cos & BOS & DP \\
\hline \multirow[t]{3}{*}{ OPP10 } & 1698 & - & - & + \\
\hline & 603 & - & + & - \\
\hline & 425 & + & - & - \\
\hline \multirow[t]{3}{*}{ AH29 } & 1190 & - & + & - \\
\hline & 1135 & + & - & + \\
\hline & 800 & + & - & + \\
\hline \multirow[t]{2}{*}{ AG1 } & 550 & - & + & - \\
\hline & 260 & + & - & + \\
\hline \multirow[t]{4}{*}{ OPP12 } & 1170 & - & + & + \\
\hline & 1350 & - & + & - \\
\hline & 832 & - & - & + \\
\hline & 692 & - & - & + \\
\hline \multirow[t]{5}{*}{ OPA07 } & 1114 & + & - & + \\
\hline & 1072 & + & - & + \\
\hline & 517 & + & - & + \\
\hline & 407 & - & + & - \\
\hline & 340 & - & + & - \\
\hline \multirow[t]{4}{*}{ OPP14 } & 1230 & - & + & + \\
\hline & 725 & + & + & - \\
\hline & 625 & + & - & + \\
\hline & 210 & + & - & + \\
\hline \multirow[t]{4}{*}{ ОРP02 } & 1260 & + & - & + \\
\hline & 800 & + & - & - \\
\hline & 750 & - & + & - \\
\hline & 530 & + & - & + \\
\hline
\end{tabular}

Table 2. Polymorphic fragments scored among the Columnar genotype (COS), Bush genotype (BOS), and Donor Plant (DP)

In 2004, a second RAPD analysis, conducted using the same 20 primers considered in the initial molecular analysis, was performed on 12-year-old somaclonal plants (the plant age refers to the time from transfer to ex vitro conditions). The RAPD analysis of the mature olive plants ( Figures 9,10) confirmed all patterns of differences between the somaclones and donor plant obtained in the initial study. Moreover, the bands specific to BOS and COS were confirmed. Therefore, when reproducibility is strictly controlled, the RAPD system still seems to be the most rapid and inexpensive for testing variability among plants obtained by somatic embryogenesis. This study indicated clearly that the somaclonal variation in olive was stable and confirmed the morphological results obtained in previous years . 

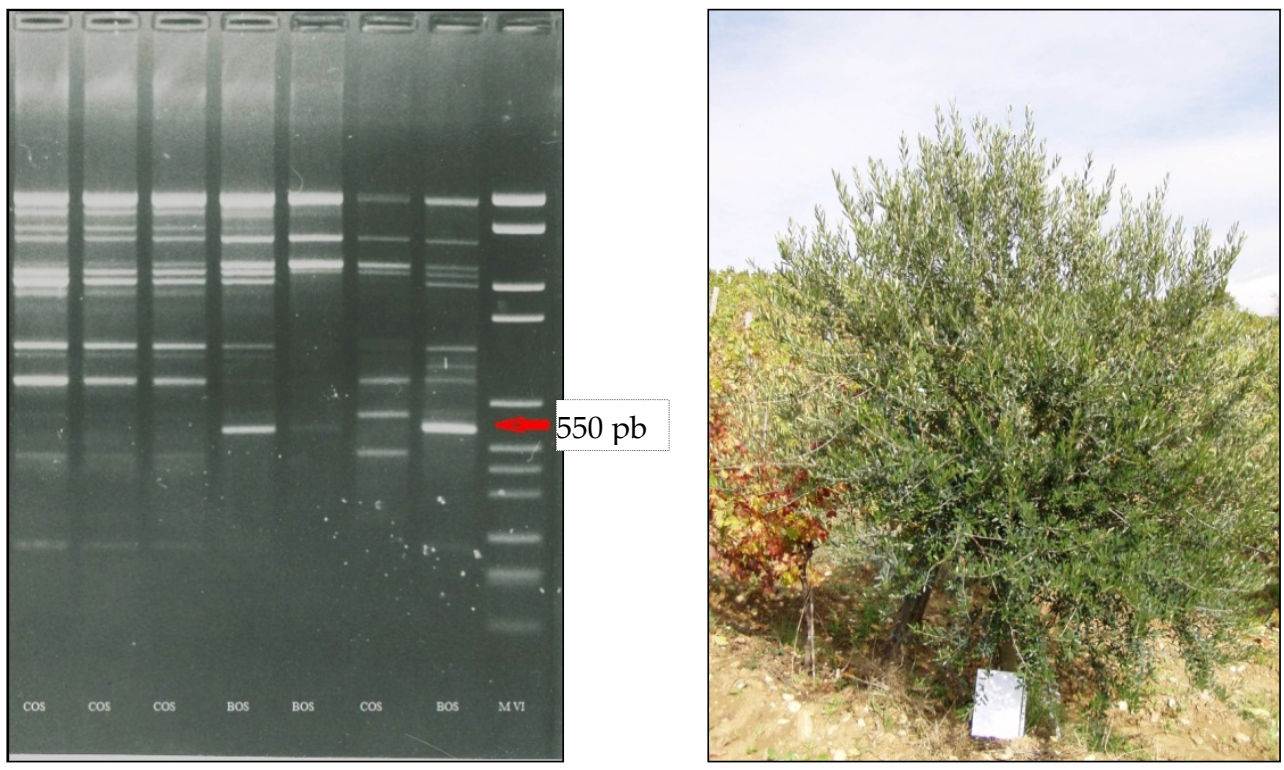

Figure 9. RAPD-PCR amplification patterns for somaclonal olive plants BOS using AG1 primer. Polymorphic DNA fragment is identified by an arrow

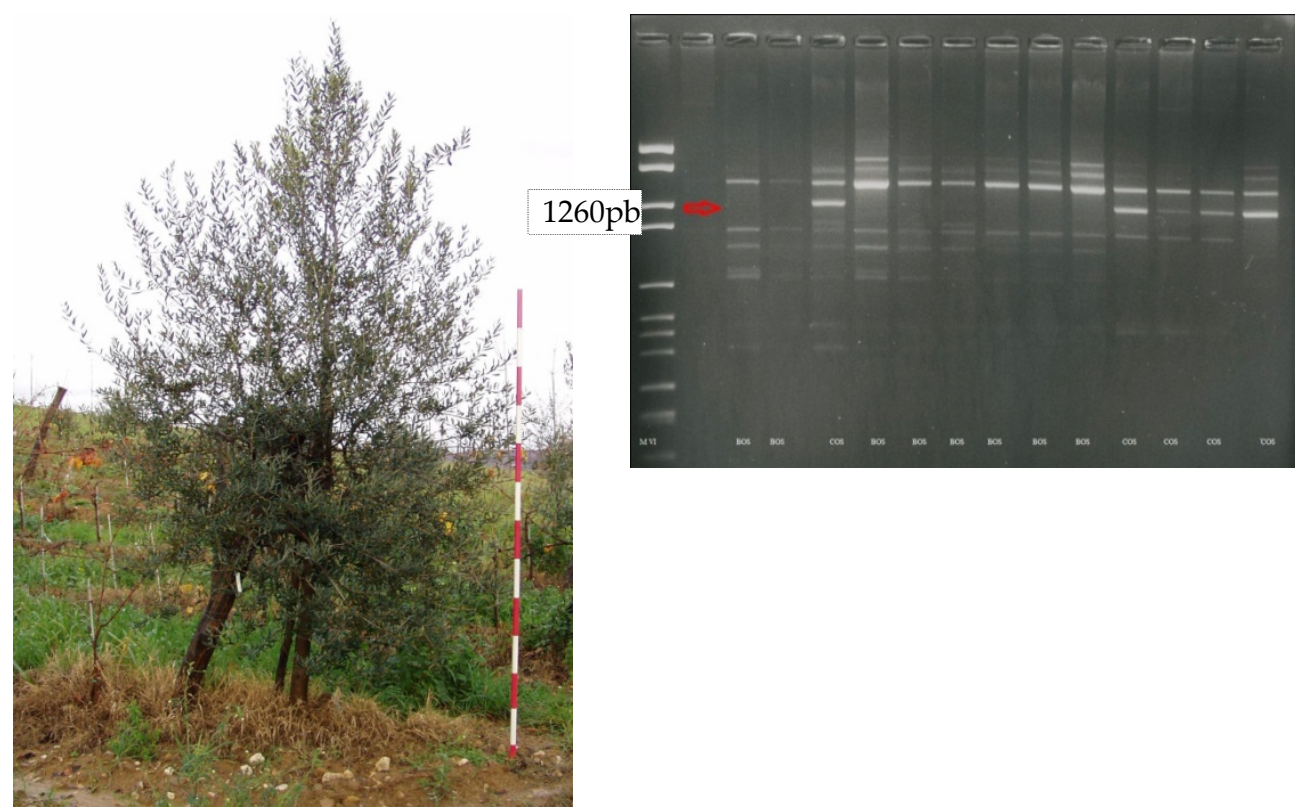

Figure 10. RAPD-PCR amplification patterns for somaclonal olive plants COS using OPP02 primer. Polymorphic DNA fragment is identified by an arrow 


\subsubsection{Description of morphological variation among the vegetative progeny of somaclonal} plants

In view of the stringent requirements for the adoption of novel olive genetic material by working breeders, the variation detected must be hereditable, either sexually or asexually, through conventional vegetative propagation. The aim of our studies on somaclones has been to determine whether the variation in habit is also expressed in the progeny of somaclonal olive plants (daughter plants) obtained by vegetative propagation (rooted cuttings). Data for both the rooting capacity of somaclonal plants and its behaviour under field conditions are reported for 2005 and 2009 respectively.

\begin{tabular}{|c|c|c|c|}
\hline Type of habitus & $\begin{array}{c}\text { Rooting } \\
(\%)\end{array}$ & Root number & $\begin{array}{c}\text { Root length } \\
(\mathrm{cm})\end{array}$ \\
\hline Columnar (COS) & $64.41 \mathrm{n} . \mathrm{s}$ & $5.5 \mathrm{n} . \mathrm{s}$ & $2.45 \mathrm{n} . \mathrm{s}$ \\
\hline Dwarf (BOS) & $61.15 \mathrm{n} . \mathrm{s}$ & $4.8 \mathrm{n} . \mathrm{s}$ & $2.57 \mathrm{n} . \mathrm{s}$ \\
\hline
\end{tabular}

Means were discriminated using Tukey's multiple range test at the $5 \%$ level of significant

Table 3. Rooting percentages of the BOS and COS somaclonal olive plants

The BOS and COS variant phenotypes showed a medium-high rooting capacity, with no statistical differences for the parameters studied between the two types of growth habit (Table 3).

Furthermore, in 2006, under an agreement with the Centro di Ricerca e Sperimentazione in Agricoltura (CRSA) "Basile Caramia" Locorotondo, Taranto, Italy, the propagated daughter somaclonal plants were planted in an experimental field at Vivai Conca d'Oro at Palagianello, (40³4'43" N, 1658'31" E, m. 32 a.s.l.) to verify both the heritability of the habit variation and the behaviour of habit variation in very different environmental conditions. This approach was based on the premiss that the performance of BOS and COS plants might depend not only on their inherent growth habit, but also on the environmental conditions in which they were grown. The environment could limit or enhance the expression of morphological growth phenotypes.

\begin{tabular}{|c|c|c|c|c|c|c|}
\hline Type of habitus & $\begin{array}{c}\text { Plant } \\
\text { Height } \\
\mathrm{m}\end{array}$ & $\begin{array}{c}\text { Trunk } \\
\text { diameter } \\
\mathrm{cm}\end{array}$ & $\begin{array}{c}\text { Length of } \\
\text { lateral } \\
\text { shoots } \mathrm{cm}\end{array}$ & $\begin{array}{c}\text { Node } \\
\text { number of } \\
\text { lateral } \\
\text { shoots }\end{array}$ & $\begin{array}{c}\text { axillary } \\
\text { shoot } \\
\text { number }\end{array}$ & $\begin{array}{c}\text { Node } \\
\text { number of } \\
\text { axillary } \\
\text { shoots }\end{array}$ \\
\hline Columnar (COS) & $3.2 \mathrm{a}$ & $11.1 \mathrm{~ns}$ & $76.1 \mathrm{a}$ & $39.5 \mathrm{a}$ & $1.9 \mathrm{c}$ & $5.9 \mathrm{~b}$ \\
\hline Dwarf (BOS) & $2.4 \mathrm{~b}$ & $10.0 \mathrm{~ns}$ & $65.9 \mathrm{~b}$ & $31.8 \mathrm{~b}$ & $11.8 \mathrm{a}$ & $11.6 \mathrm{a}$ \\
\hline Putative control & $3.0 \mathrm{a}$ & $9.4 \mathrm{~ns}$ & $55.8 \mathrm{c}$ & $27.6 \mathrm{~b}$ & $6.0 \mathrm{~b}$ & $5.7 \mathrm{~b}$ \\
\hline
\end{tabular}

Means were discriminated using Tukey's multiple range test at the $5 \%$ level of significant

Table 4. Comparison of daughter somaclonal olive plants of columnar and dwarf: plant height, trunk diameter, length and node number of lateral and axillary shoots 
Preliminary assessment of the performance of somaclonal daughter plants, conducted for 3 years, indicated that morphological characteristics were comparable to those of the somaclonal mother plants. As in the mother plants, the main morphological patterns were the plant height for the BOS phenotype, and length, node number and number of axillary shoots for both phenotypes, in comparison to the putative control (Table 4). In addition, in relation to the environmental conditions at the planting site, the growth performance of the somaclonal daughter plants depended only on the inherent growth habit (Figure 11).

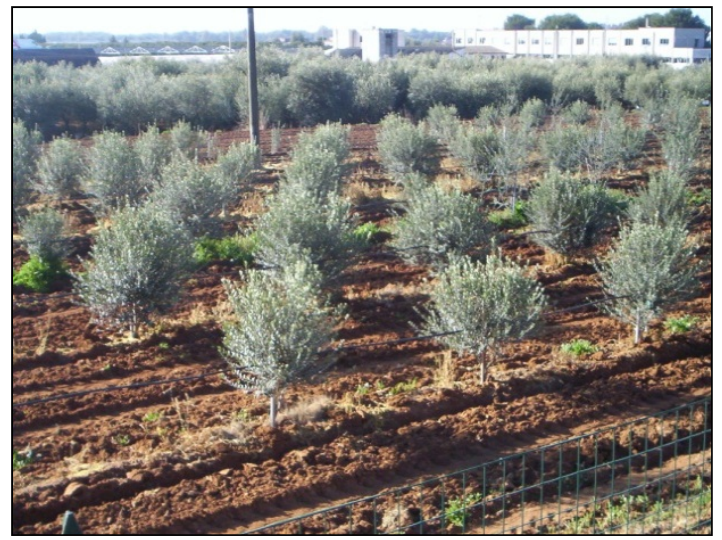

Figure 11. Daughter somaclonal olive plants in experimental field at CRSA

\section{Conclusion}

Although most perennial plant species are classified as recalcitrant to regeneration by in vitro tissue culture, over the last two decades, enormous progress has been made in the application of biotechnological tools to the Olea europaea. The development of several protocols for micropropagation from axillary buds and somatic embryogenesis using explants isolated from selected adult trees has allowed the regeneration of several olive cultivars. However, the main challenge for mass production of olive plants by tissue culture is the production of plants that show genetic fidelity to the donor plant in a commercial production context. Fidelity is assured by the application of micropropagation by axillary buds, whereas somatic embryogenesis from long-term cultures does not guarantee genetic fidelity and leads to somaclonal variation among the regenerated plants.

Somaclonal variation in tissue culture is a complex problem that needs several approaches to be appreciated correctly. The use of only one type of molecular marker, such as RAPDs, to assess the genetic stability of an in vitro production system may be inadequate, and an approach that focuses on morphological traits appears to be a valuable complementary tool. For example, the analysis of morphological traits strongly confirms the specific and stable growth habit of regenerated plants by the analysis of vegetative progeny of somaclonal olive plants. 
Future studies will be focused on target DNA fragments (AG1550, OPA07407, $1281_{640}$ and OPP02759) putatively associated with growth habit. These fragments were extracted from agarose gels and purified using the QIAquick Gel Extraction Kit (Qiagen), and the eluted putative growth habit-specific genes were cloned. Database searches for homologous sequences using the BLAST tool will be performed and, in addition, we are designing related oligonucleotide primers that will be synthesized and used to amplify sequence characterised amplified region (SCAR) markers.

The somaclonal variation generated by somatic embryogenesis presents a novel opportunity for olive breeders to experiment with new traits, in contrast to conventional long-term strategies for developing olive trees that have desirable new traits. A practical example of this potential is a dwarf olive tree identified among the BOS plants; the aesthetic, ecological and growth-habit characteristics of this individual support its use as an ornamental plant. Clones of this dwarf olive genotype could be planted in private gardens, public parks and on roadsides [137].

A.R. Leva produced the olive somaclones and has the exclusive rights on them.

R. Petruccelli and L.M.R. Rinaldi contributed to the morphological and molecular characterization of the olive somaclones.

\section{Author details}

A.R. Leva*, R. Petruccelli and L.M.R. Rinaldi

CNR IVALSA Trees and Timber Institute, Firenze, Italy

\section{Acknowledgement}

The authors wish to thank the Centro di Ricerca e Sperimentazione in Agricoltura (CRSA)“Basile Caramia” Locorotondo, Taranto, Italy and the University Department DPPMA and Vegetal Virology Institute CNR in Bari (Italy) for maintaining the daughter somaclonal olive plants.

\section{References}

[1] Rani V, Raina S. Genetic fidelity of organized meristemderived micropropagated plants: a critical reappraisal. In Vitro Cellular Developmental Biology Plant 2000; 36: 319-330.

[2] Rani V, Parida A, Raina S. Random amplified polymorphic DNA (RAPD) markers for genetic analysis in micropropagated plants of Populus deltoides Marsh. Plant Cell Report $1995 ; 14: 459-462$.

[3] Steward FC. Growth and development of cultivated cells. III. Interpretation of the growth from free cell to carrot plant. American Journal of Botany 1958; 45:709-713.

\footnotetext{
${ }^{*}$ Corresponding Author
} 
[4] Braun AC. A demonstration of the recovery of the crown-gall tumor cell with the use of complex tumors of single-cell origin. Proceedings of the National Academy of Sciences of the United States of America 1959; 45 : 932-938.

[5] Larkin P, Scowcroft W. Somaclonal variation a novel source of variability from cell cultures for plant improvement. Theoretical and Applied Genetics 1981; 60: 197-214.

[6] Karp A. Origins, causes and uses of variation in plant tissue cultures. In: Vasil IK, Thorpe TA (eds) Plant cell and tissue culture. Dordrecht : Kluwer Academic Publishers; 1994. p 139-152.

[7] Orbovic'V, Calovic'M, Viloria Z, Nielsen B, Gmitter F, Castle W, Grosser J. Analysis of genetic variability in various tissue culture-derived lemon plant populations using RAPD and flow cytometry. Euphytica 2008;161: 329-335.

[8] Skirvin RM, McPheeters KD, Norton M. Sources and frequency of somaclonal variation. HortScience 1994; 29:1232-1237.

[9] Kaeppler SM, Kaeppler HF, Rhee Y. Epigenetic aspects of somaclonal variation in plants. Plant Molecular Biology 2000; 43:179-188.

[10] Mehta YR, Angra DC. Somaclonal variation for disease resistance in wheat and production of dihaploids through wheat 9 maize hybrids. Genetics and Molecular Biology 2000; 23:617-622.

[11] Predieri S. Mutation induction and tissue culture in improving fruits. Plant Cell Tissue Organ Culture 2001; 64:185-210.

[12] Karp A. Somaclonal variation as a tool for crop improvement. Euphytica 1995; 85 295-302.

[13] Unai E, Iselen T, de Garcia E. Comparison of characteristics of bananas (Musa sp.) from the somaclone CIEN BTA-03 and its parental clone Williams. Fruit 2004; 59: 257-263.

[14] Skirvin RM, Norton M, McPheeters KD. Somaclonal variation:has it proved useful for plant improvement? Acta Horticulturae 1993; (336) 333-340.

[15] Skirvin RM, McPheeters KD, Norton M. Sources and frequency of somaclonal variation. HortScience 1994; 29 : 1232-1237.

[16] Pierik RLM. In vitro culture of higher plants. Kluwer Academic Publishers, Dordrecht; 1987.

[17] Skirvin RM Natural and induced variation in tissue culture. Euphytica 1978; 27: 241266.

[18] Scowcroft WR. Genetic variability in tissue culture: impact on germplasm conservation and utilization. International board for plant genetic resources (IBPGR) technical report AGPGIBPGR/84/152, Rome; 1984.

[19] Sivanesan I. Shoot regeneration and somaclonal variation from leaf callus cultures of Plumbago zeylanica Linn. Asian Journal of Plant Science 2007; 6: 83-86.

[20] Vasil IK. Automation of plant propagation. Plant Cell Tissue Organ Culture 1994; 9:105108.

[21] Ammirato PV, Styer DJ. Strategies for large scale manipulation of somatic embryos in suspension culture. In: Zaitlin M, Day P, Hollaender A. (eds.) Biotechnology in plant science: relevance to agriculture in the eighties. New York: Academic Press; 1985. 161- 178.

[22] Lutz JD, Wong JR, Rowe J, Tricoli DM, Lawrence RHJ. Somatic embryogenesis for mass cloning of crop plants. In: Henke RR, Hughes KW, Constantin MP, Hollaender A. (eds.)Tissue culture in forestry and agriculture. New York: Plenum; 1985. p105-116. 
[23] Redenbaugh K, Viss P, Slade D, Fujii JA. Scale-up: artificial seeds. In: Green CE, Somers DA, Hackett WP, Biesboer DD. (eds.) Plant tissue and cell culture. New York: A. R. Liss; 1987. 473-493.

[24] Thorpe TA. Frontiers of plant tissue culture. Canada: University of Calgary Press; 1978.

[25] Thorpe TA. In vitro somatic embryogenesis. ISI atlas of science-animal and plant sciences. 1988; 1: 81-88.

[26] Debergh PC, Read PE. Micropropagation. In: Debergh PC, Zimmerman RH.(eds.) Micropropagation, technology and application. Dordrecht, Boston, London: Kluwer Academic; 1990. 1-13.

[27] Wang, P. J.; Charles, A. Micropropagation through meristem culture. In: Bajaj YPS. (ed.) Biotechnology in agriculture and forestry, HighTech and micropropagation I. New York: Springer Verlag 1991; (17) 32-52.

[28] Vasil IK. Somatic embryogenesis and its consequences in gramineae. In:Henke R, Hughes K, Constantin M, Hollaender A. (eds) Tissue culture in forestry and agriculture. New York: Plenum Press; 1985. p 31-47.

[29] Shenoy VB, Vasil IK. Biochemical and molecular analysis of plants derived from embryogenic cultures of napier grass (Pennisetum purpureum K. Schum.). Theoretical and Applied Genetics 1992; 83: 947-955.

[30] Murashige T.The impact of plant tissue culture on agriculture. In: Thorpe TA (ed.) Frontiers of plant tissue culture. Calgary: University of Calgary, International Association for Plant Tissue Culture; 1978. 15-26.

[31] Hammerschlag, FA. Factors influencing the frequency of callus formation among cultured peach anthers. HortScience 1984; 19:554.

[32] Gupta PK, Mascarenhas AF. Eucalyptus. In: Bonga JM, Durzan DJ (eds.) Cell and tissue culture in forestry. Dordrecht: Martinus Nijhoff; 1987. Vol. 3.p385-399.

[33] Eastman PAK, Webster FB, Pitel JA, Roberts DR. Evaluation of somaclonal variation during somatic embryogenesis of interior spruce (Picea engelmannii complex) using culture morphology and isozyme analysis. Plant Cell Report 1991; $10: 425-430$.

[34] Isabel N, Tremblay L, Michaud M, Tremblay FM, Bousquet J. RAPDs as an aid to evaluate the genetic integrity of somatic embryogenesis derived populations of Picea mariana (Mill.) B.S.P. Theoretical and Applied Genetics 1993; 86 81-87.

[35] Gavidia I, Del Castillo ALD, Perez-Bermudez V. Selection of long-term cultures of high yielding Digitalis obscura plants: RAPD markers for analysis of genetic stability. Plant Science 1996; 121:197-205.

[36] Jain SM. Tissue culture-derived variation in crop improvement. Euphytica 2001; 118:153-166.

[37] Krikorian AD, Irizarry H, Cronauer-Mitra SS, Rivera E. Clonal fidelity and variation in plantain (Musa AAB) regenerated from vegetative stem and floral axis tips in vitro. Annals of Botany 1993; 71:519-535.

[38] Kawiak A, Łojkowska E. Application of RAPD in the determination of genetic fidelity in micropropagated Drosera plantlets. In Vitro Cellular Developmental Biology Plant 2004; 40:592-595.

[39] Chuang SJ, Chen CL, Chen JJ, Chou WY, Sung JM. Detection of somaclonal variation in micro-propagated Echinacea purpurea using AFLP marker. Scientia Horticulturae 2009; 120:121-126. 
[40] Sahijram L, Soneji J, Bollamma K. Analyzing somaclonal variation in micropropagated bananas (Musa spp.). In Vitro Cellular Developmental Biology Plant 2003;39:551-556.

[41] Sharma S, Bryan G, Winfield M, Millam S. Stability of potato (Solanum tuberosum L.) plants regenerated via somatic embryos, axillary bud proliferated shoots, microtubers and true potato seeds: a comparative phenotypic, cytogenetic and molecular assessment. Planta 2007; 226:1449-1458.

[42] Kunitake H, Koreeda K, Mii M. Morphological and cytological characteristics of protoplast-derived plants of statice (Limonium perezii Hubbard). Scientia Horticulturae 1995; 60:305-312.

[43] Swartz H J. Post culture behaviour, genetic and epigenetic effects and related problems. In: Debergh PC, Zimmerman RH (eds.) Micropropagation: technology and application. Dodrecht : Kluwer Academic Publishers; 1991.p 95-122.

[44] Vidal M D C, De Garcià E. Analysis of a Musa spp. Somaclonal variant resistant to yellow Sigatoka. Plant Molecular Biology Reporter 2000; 18: 23-31.

[45] Martin K, Pachathundikandi S, Zhang C, Slater A, Madassery J. RAPD analysis of a variant of banana (Musa sp.) cv. grande naine and its propagation via shoot tip culture. In Vitro Cellular Developmental Biology Plant 2006; 42:188-192.

[46] LoSchiavo F, Pitto L, Giuliano G, Torti G, Nuti-Ronchi V, Marazziti D, Vergara R, Orselli S, Terzi M. DNA methylation of embryogenic carrot cell cultures and its variations as caused by mutation, differentiation, hormones and hypomethylating drugs. Theoretical and Applied Genetics 1989; 77:325-331.

[47] Nehra NS, Kartha KK, Stushnott C, Giles KL. The influence of plant growth regulator concentrations and callus age on somaclonal variation in callus culture regenerants of strawberry. Plant Cell Tissue Organ Culture 1992; 29:257-268.

[48] Bouman H, De Klerk GJ. Measurement of the extent of somaclonal variation in begonia plants regenerated under various conditions. Comparison of three assays. Theoretical and Applied Genetics 2001;102: 111-117.

[49] Ahmed EU, Hayashi T, Yazawa S. Auxins increase the occurrence of leaf-colour variants in Caladium regenerated from leaf explants. Scientia Horticulturae 2004; 100:153-159.

[50] Mohanty S, Panda M, Subudhi E, Nayak S. Plant regeneration from callus culture of Curcuma aromatica and in vitro detection of somaclonal variation through cytophotometric analysis. Biologia Plantarum 2008; 52:783-786.

[51] Bayliss MW. Chromosomal variation in tissue culture. In:Vasil IK (ed.) Perspectives in plant cell and tissue culture. New York : Academic Press; 1980.p113-144.

[52] Venkatachalam L, Sreedhar RV, Bhagyalakshmi N. Genetic analyses of micropropagated and regenerated plantlets of banana as assessed by RAPD and ISSR markers. In Vitro Cellular Developmental Biology Plant 2007a; 43:267-274.

[53] Reuveni O, Israeli Y, Golubowicz S. Factors influencing the occurrence of somaclonal variations in micropropagated bananas. Acta Horticulturae 1993; 336:357-364.

[54] Giménez C, de García E, de Enrech NX, Blanca I. Somaclonal variation in banana: cytogenetic and molecular characterization of the somaclonal variant CIEN BTA-03. In Vitro Cellular Developmental Biology Plant 2001; 37:217-222. 
[55] Roels S, Escalona M, Cejas I, Noceda C, Rodriguez R, Canal MJ, Sandoval J, Debergh P Optimization of plantain (Musa $\mathrm{AAB}$ ) micropropagation by temporary immersion system. Plant Cell Tissue Organ Culture 2005; 82:57-66.

[56] Reuveni O, Israeli Y Measures to reduce somaclonal variation in in vitro propagated bananas. Acta Horticulturae 1990; 275:307-313.

[57] Rodrigues PHV, Tulmann Neto A, Cassieri Neto P, Mendes BMJ. Influence of the number of subcultures on somoclonal variation in micropropagated Nanico (Musa spp., AAA group). Acta Horticulturae 1998; 490:469-473.

[58] Bairu MW, Fennell CW, van Staden J The effect of plant growth regulators on somaclonal variation in Cavendish banana (Musa AAA cv. 'Zelig'). Scientia Horticulturae 2006; 108:347-351.

[59] Israeli Y, Lahav E, Reuveni O. In vitro culture of bananas. In:Gowen S (ed.) Bananas and plantians. Chapman and Hall, London, 1995.p 147-178.

[60] Petolino JF, Roberts JL, Jayakumar P. Plant cell culture: a critical tool for agricultural biotechnology. In: Vinci VA, Parekh SR (eds.) Handbook of industrial cell culture: mammalian, microbial and plant cells. New Jersey : Humana Press; 2003.p 243-258.

[61] Cote F, Teisson C, Perrier X Somaclonal variation rate evolution in plant tissue culture: contribution to understanding through a statistical approach. In Vitro Cellular Developmental Biology Plant 2001; 37:539-542.

[62] Kaeppler S, Phillips R. DNA methylation and tissue culture induced variation in plants. In Vitro Cellular Developmental Biology Plant 1993; 29: 125-130.

[63] Shepherd K, Dos Santos JA Mitotic instability in banana varieties. I. Plants from callus and shoot tip cultures. Fruit 1996; 51:5-11.

[64] Popescu AN, Isac VS, Coman MS MSR Somaclonal variation in plants regenerated by organogenesis from callus cultures of strawberry (Fragaria 9 ananassa) Acta Horticulturae 1997; 439:89-96.

[65] Lee M, Phillips RL.The Chromosomal basis of somaclonal variation. Annual Review of Plant Physiology Plant Molecular Biology 1988; 39:413-437.

[66] Damasco OP, Smith MK, Adkins SW, Hetherington SE, Godwin ID. Identification and characterisation of dwarf off-types from micropropagated 'Cavendish' bananas. Acta Horticulturae 1998; 490:79-84.

[67] Stover RH. Somaclonal variation in Grande Naine and Saba bananas in the nursery and in the field. In: Persley GJ, De Langhe E (eds.) ACIAR proceeding no. 21, Canberra; 1987.

[68] Israeli Y, Reuveni O, Lahav E. Qualitative aspects of somaclonal variations in banana propagated by in vitro techniques. Scientia Horticulturae 1991; 48:71-88.

[69] Martin K, Pachathundikandi S, Zhang C, Slater A, Madassery J. RAPD analysis of a variant of banana (Musa sp.) cv. grande naine and its propagation via shoot tip culture. Plant 2006; 42:188-192.

[70] D'Amato F. Cytogenetics of differentiation in tissue and cell culture. In: Reinert J, Bajaj YPS (eds.) Applied and fundamental aspects of plant cell, tissue and organ culture. New York : Springer; 1977, p 343-464. 
[71] Hao Y-J, Deng X-X. Occurrence of chromosomal variations and plant regeneration from long-term-cultured citrus callus. In Vitro Cellular Developmental Biology Plant 2002; 38:472-476.

[72] Mujib A, Banerjee S, Dev Ghosh P. Callus induction, somatic embryogenesis and chromosomal instability in tissue culture raised hippeastrum (Hippeastrum hybridum cv. United Nations). Propagation of Ornamental Plants 2007; 7:169-174.

[73] Hirochika H Activation of tobacco transposons during tissue culture. EMBO J 1993; 12:2521-2528.

[74] Barret P, Brinkman M, Beckert M. A sequence related to rice Pong transposable element displays transcriptional activation by in vitro culture and reveals somaclonal variations in maize. Genome 2006; 49:1399-1407.

[75] Smulders MJM, de Klerk G J. Epigenetics in plant tissue culture. Plant Growth Regulation 2011; 63:137-146

[76] Jaligot E, Rival A, Beule' T, Dussert S, Verdeil JL Somaclonal variation in oil palm (Elaeis guineensis Jacq.): the DNA methylation hypothesis. Plant Cell Report 2000; 19:684-690.

[77] Schellenbaum P, Mohle V, Wenzel G, Walter B. Variation in DNA methylation patterns of grapevine somaclones (Vitis vinifera L.) BMC Plant Biology 2008; 8:78-88.

[78] Baránek M., Křižan B., Ondružıková E., Pidra M. DNA methylation changes in grapevine somaclones following in vitro culture and thermotherapy. Plant Cell Tissue Organ Culture 2010; 101:11-22.

[79] Li X, Xu M, Korban S S. DNA methylation profiles differ between field- and in vitrogrown leaves of apple. Journal of Plant Physiology 2002; 159: 1129-1134.

[80] Hammerschlag FA. Somaclonal variation. In: Hammerschlag FA Litz RE (eds)CAB International Biotechnology of Perennial Fruit Crops. Wallingfors, 1992. p 35-36.

[81] Karp, A. On the current understanding of somaclonal variation. In: Miflin B J (ed.), Surveys of Plant Molecular and Cell Biology, Oxford University Press; 1982.7: 1-58.

[82] Piagnani M C, Maffi D, Rossoni M, Chiozzotto R. Morphological and physiological behaviour of sweet cherry 'somaclone' HS plants in field. Euphytica 2008; 160:165-173.

[83] Faure O, Nougarède A. Nuclear DNA content of somatic and zygotic embryos of Vitis vinifera $\mathrm{cv}$. Grenache Noir at the torpedo stage-flow cytometry and in situ DNA microspectrophotometry. Protoplasma 1993; 176:145-150.

[84] Kuksova VB, Piven NM, Gleba YY Somaclonal variation and in vitro induced mutagenesis in grapevine. Plant Cell Tissue Organ Culture 1997; 49:17-27.

[85] Leal F, Loureiro J, Rodriguez E, Pais MS, Santos C,Pinto-Carnide O. Nuclear DNA content of Vitis vinifera cultivars and ploidy level analyses of somatic embryo-derived plants obtained from anther culture. Plant Cell Report 2006; 25: 978-985.

[86] Carini F, De Pasquale F. Micropropagation of Citrus. In Micropropagation of Wood Tree and Fruits. S Mohan and katsuaki Ishii (ed.). London : Kluwer Academic Publishers ; 2003; 75:589-619.

[87] Fourré JL Somaclonal variation and genetic molecular markers in woody plants. In: Jain SM, Minocha SC (eds.) Molecular biology of woody plants. The Netherlands : Kluwer; 2000. p. 425-449 
[88] Veilleux RE, Johnson AAT. Somaclonal variation: Molecular analysis, transformation, interaction, and utilization. Plant Breeding Reviews 1998;16: 229-268.

[89] Hashmi G, Huettel R, Meyer R, Krusberg L, Hammerschlag F. RAPD analysis of somaclonal variants derived from embryo callus cultures of peach. Plant Cell Report 1997; 16:624-627.

[90] Piola F, Rohr R, Heizmann P. Rapid detection of genetic variation within and among in vitro propagated cedar (Cedrus libani Loudon) clones. Plant Science 1999; 141:159-163.

[91] Renau-Morata B, Nebauer SG, Arrillaga I, Segura J. Assessments of somaclonal variation in micropropagated shoots of cedrus: consequences of axillary bud breaking. Tree Genetics and Genomes 2005; 1: 3-10.

[92] Khan EU, Fu XZ, Wang J, Fan QJ, Huang XS, Zhang GN, Shi J, Liu JH Regeneration and characterization of plants derived from leaf in vitro culture of two sweet orange (Citrus sinensis (L.) Osbeck) cultivars. Scientia Horticulturae 2009; 120:70-76.

[93] Oliveira CM, Mota M, Monte-Corvo L, Goulão L, Silva DM. Molecular typing of Pyrus based on RAPD markers. Scientia Horticulturae 1999; 79: 163-174.

[94] Nas M N, Multu N, Read PE. Random amplified polimorfic DNA (RAPD) analysis. HortScience 2004; 39:1079-1082.

[95] Virscek-Marn M, Bohanec B, Javornik B. (1999) Adventitious shoot regeneration from apple leaves optimisation of the protocol and assessment of genetic variation among regenerants. Phyton 39: 61-70.

[96] Caboni E, Lauri P, Damiano C, D'Angeli S. Somaclonal variation induced by adventitious shoot regeneration in pear and apple. Acta Horticulture 2000; 530: 195-202.

[97] Carvalho LC, Goulao L, Oliveira C, Gonçalves JC, Amancio S. RAPD assessment for identification of clonal identity and genetic stability of in vitro propagated chestnut hybrids. Plant Cell Tissue Organ Culture 2004;77: 23-27.

[98] Prado MJ, Herrera MT, Vázquez RA, Romo S, González MV. Micropropagation of two selected male kiwifruit and analysis of genetic variation with AFLP markers. HortScience 2005; 40: 740-746.

[99] Prado MJ, Gonzalez MV, Romo S, Herrera MT. Adventitious plant regeneration on leaf explants from adult male kiwifruit and AFLP analysis of genetic variation. Plant Cell Tissue Organ Culture 2007; 88: 1-10.

[100] Popescu C F, Flak A, Glimelius K. Application of AFLPs to characterize somaclonal variation in anther-derived grapevines. Vitis 2002; 41:177-182.

[101] Xiangqian Li, Mingliang Xu, Schuyler S. Korban DNA methylation profiles differ between field- and in vitro-grown leaves of apple. Journal Plant Physiology 2002; 159: 1229-1234.

[102] Martinelli L, Zambanini J, Grando MS. Genotype assessment of grape regenerants from floral explants. Vitis 2004; 43:119-122.

[103] Nookaraju A, Agrawal DC. Genetic homogeneity of in vitro raised plants of grapevine cv. Crimson Seedless revealed by ISSR and microsatellite markers. South African Journal of Botany 2012; 78: 302-306.

[104] Pathak H, Dhawan V. ISSR assay for ascertaining genetic fidelity of micropropagated plants of apple rootstock Merton 793.In Vitro Cellular Developmental Biology Plant 2012; 48: 137-143. 
[105] Palombi MA, Damiano C. Comparison between RAPD and SSR molecular markers in detecting genetic variation in kiwifruit (Actinidia deliciosa A Chev). Plant Cell Rep 2002; 20: 1061-1066.

[106] Sarmento D, Martins M, Oliveira MM. Evaluation of somaclonal variation in almond using RAPD and ISSR. Options Méditerranéennes, Série A 2005; 63: 391-395.

[107] Gribaudo I, Torello Marinoni D, Gambino G, Mannini F, Akkak A, Botta R. Assessment of genetic fidelity in regenerants from two Vitis vinifera cultivars Acta Horticulturae 2009; 827:131-136.

[108] Bonga JM, Klimaszewska KK, von Aderkas P. Recalcitrance in clonal propagation, in particular of conifer. Plant Cell Tissue Organ Culture 2010; 100:241-254.

[109] Schaeffer WI. Terminology associated with cell, tissue and organ culture, molecular biology and molecular genetics. In Vitro Cellular Developmental Biology Plant 1990; 26: 97-101.

[110] Grossoni P. Problems concerning the in vitro culture of Olea europaea L. Giornale Botanico Italiano 1979; 113:75-88.

[111] Rugini E. In vitro propagation of some (Olea europaea L.) cultivars with different rootability and medium development using analytical data from developing shoots and embryos. Scientia Horticulturae 1984; 24: 123-134.

[112] Fiorino P, Leva AR. Investigations on the micropropagation of the olive (Olea europaea L.) and influence of some mineral elements on the proliferation and rooting of explants. Olea 1986; 17: 101-104.

[113] Leva AR, Petruccelli R, Muleo R, Goretti R, Bartolini G. Influenza di fattori trofici, regolativi e condizioni di coltura in vitro di diverse cultivar di olivo. Atti Convegno "L'Olivicoltura Mediterranea: Stato e Prospettive della Coltura e della Ricerca. Rende 26-28 Gennaio 1995. p239-248.

[114] Grigoriadou K, Vasilakakis M, Eleftheriou EP In vitro propagation of the Greek olive cultivar "Chondrolia Chalkidikis". Plant Cell Tissue Organ Culture 2002; 71: 47-54.

[115] Leva AR, Sadeghi H, Petruccelli R. Carbohydrates Modulate the In Vitro Growth of Olive Microshoots. I. The Analysis of Shoot Growth and Branching Patterns. Journal of Plant Growth Regulation 2012. DOI 10.1007/s00344-012-9275-7

[116] Leva AR. Innovative protocol for "ex vitro rooting" on olive micropropagation Central European Journal of Biology. 2011; 6(3) : 352-358.

[117] Rugini E. Somatic embryogenesis and plant regeneration in Olive (Olea europaea L.). Plant Cell Tissue and Organ Culture 1988; 14: 207-214.

[118] Leva AR, Muleo R, Petruccelli R Long-term somatic embryogenesis from immature olive cotyledons. Journal Horticultural Science (1995b); 70: 417-421.

[119] Rugini E, Caricato G. Somatic embryogenesis and recovery from mature tissues of olive cultivars (Olea europaea L.) "Canino" and "Moraiolo". Plant Cell Report 1995; 14 : 257-260.

[120] Peyvandi M, Dadashian A, Ebrahimzadeh A, Majd A. Embryogenesis and rhizogenesis in mature zygotic embryos of olive (Olea europaea L.) cultivars Mission and Kroneiki. Journal of Sciences, Islamic Republic of Iran 2001; 12(1):9-15. 
[121] Trabelsi EB, Bouzid S, Bouzid M, EIIoumi N, Belfeleh Z, Benabdallah A, and Ghezel R In Vitro Regeneration of Olive Tree by Somatic Embryogenesis Journal of Plant Biology 2003; 46: 173-180.

[122] Peyvandi M, Nemat Farahzadi H, Arbabian S, Noormohammadi Z, HosseiniMazinani M. Somaclonal Variation Among Somatic-Embryo Derived Plants of Olea europaea L "cv. Kroneiki". Journal of Sciences, Islamic Republic of Iran 2010; 21 (1): 7-14.

[123] Capelo AM, Silvia S, Brito G, Santos C. Somatic embryogenesis induction in leaves and petioles of a mature wild olive. Plant Cell Tissue Organ Culture 2010; 103:237-242.

[124] Mazri MA, Elbakkali A, Belkoura M, Belkoura I. Embryogenic competence of calli and embryos regeneration from various explants of Dahbia cv, a moroccan olive tree (Olea europaea L.). African Journal of Biotechnology 2011; 10 (82):19089-19095.

[125] Trabelsi EB, Naija S, Elloumi N, Belfeleh Z, Msellem M, Ghezel R, Bouzid S. Somatic embryogenesis in cell suspension cultures of olive Olea europaea L. 'Chetoui' Acta Physiologiae Plantarum 2011; 33:319-324

[126] Briccoli Bati C, Godini G, Nuzzo V. Preliminar agronomic evaluation of two cultivars of olive trees obtained from micropropagation method. Acta Horticulture 2002; 586: 867-870.

[127] Leva AR, Petruccelli R, Montagni G, Muleo R. Field performance of micropropagated olive plants (cv Maurino): morphological and molecular features. Acta Horticulture 2002; 586: 891-894.

[128] Leva AR. Morphological evaluation of olive plants propagated in vitro through axillary buds and somatic embryogenesis methods. African Journal of Plant Science 2009; 3 (3): 37-43.

[129] Roselli G, Mariotti P, Tessa A. Caratterizzazione di progenie di olivo mediante analisi chimica e sensoriale degli olii. Proceedings del Simposio Nazionale : “Germoplasma olivicolo e tipicità dell'olio" tenuto a Perugia 5 dicembre, 2003. pp 278-283

[130] Barranco D, Rallo L. Olive cultivars in Spain. HorTechnology 2000; 10:107-110.

[131] Rotondi A, Magli M, Ricciolini C, Baldoni L. Morphological and molecular analyses for the characterization of a group of Italian olive cultivars. Euphytica 2003; 132: 129-137.

[132] Leva AR, Petruccelli R, Polsinelli L. In vitro olive propagation: from the laboratory to the production line. OLIVAE 2004; 101: 18-26.

[133] Gucci R, Cantini C. Pruning and Training Systems for Modern Olive Growing. CSIRO Publishing, Australia 2000.

[134] Leva AR, Petruccelli R. Monitoring of cultivar identity in micropropagated olive plants using RAPD and ISSR markers. Biologia Plantarum 2012; 56 (2): 373-376.

[135] Mencuccini M.Produzione di somacloni da cultivar di olivo e prime osservazioni in campo Acta Italus Hortus 2011; 1: 113-116.

[136] Leva AR, Muleo R, Petruccelli R. Stabilità in campo di diversi habitus vegetativi in individui di Olea europaea L (cv Frangivento) derivati da embriogenesi somatica.Proceedings of the National Congress : Biodiversità-Opportunità di Sviluppo Sostenibile. Istituto Agronomico Mediterraneo, Bari, Italy. 2001.Volume II. 407-414.

[137] Leva AR, Petruccelli R. Dwarf olive trees for ornamental use: a morphological evaluation Journal of Horticultural Science \& Biotechnology 2011; 86 (3) 217-220. 